\title{
Special Issue Dedicated to Professor Frank Fisher (1943-2012): A Courageous Life
}

In 2007 Professor Frank Fisher was named Australia's inaugural Environmental Educator of the Year (by the Australian Association for Environmental Education). Frank lived a life driven by a determination to engage fully with the world around him. As a young electrical engineer, Frank became convinced of the need for education and research about how we shape the world around us, and contributed to the establishment of the first Australian Masters of Sustainability program at Monash University in 1973. Typified by exercises such as taking students to sit in the middle of major roads, Frank's teaching approach aimed to help students understand the social systems that shape our understanding of and impact on the world around us.

After over 30 years at Monash, Frank founded the Understandascope, a centre for environmental education and research to develop projects such as a pay-by-weight waste scheme, and the 'Tao of City Cycling' course. Frank became Professor of Sustainability at Swinburne's National Centre for Sustainability and also taught at OASES Graduate School.

Frank was often not well received by the wider environment movement. His scepticism of technological solutions that serve to reinforce established worldviews, and his emphasis on our personal responsibility to practise sustainability across our whole lives was an uncomfortable challenge for some. Yet Frank persisted, engaging patiently with anyone who expressed the slightest interest.

But teaching was only one part of Frank's life. Frank was courageously committed to living as sustainably as he could. Not only did he ride his bike everywhere, but when Crohn's disease threatened the requirement of a permanent drip Frank decided upon a device for attaching the drip process to his bicycle.

Diagnosed with Crohn's before he turned 20, Frank underwent over 30 operations throughout his life, but saw it more as an enlightening gift than a burden. Delivering lectures from his hospital bed, Frank used the opportunity to share with students insights from his experiences. Frank didn't just live through the terminal predictions of multiple doctors, but he did it in a way that inspires us all to re-imagine what we are capable of.

Frank's passing in August 2012 is a great loss for his family, friends, colleagues and the environmental and health sectors at large. His influence on those around him to challenge and examine what are accepted practices in living a sustainable existence is legendary. The Executive of the Australian Association for Environmental Education (AAEE) and the Victorian Association for Environmental Education (VAEE) will miss his insights, wisdom and counsel.

\section{Prepared by}

James Tonson ${ }^{1}$ \& Sarah Houseman ${ }^{2}$

${ }^{1}$ Understandascope, Melbourne, Victoria, Australia

${ }^{2}$ Victorian Association for Environmental Education, Melbourne, Victoria, Australia 